\title{
Production of Outer-membrane Proteins and an Extracellular Fluorescent Compound by Iron-limited Azomonas macrocytogenes
}

\author{
By S. KAREN COLLINSON AND WILLIAM J. PAGE* \\ Department of Microbiology, University of Alberta, Edmonton, Alberta T6G 2E9, Canada
}

(Received 21 October 1988; revised 9 January 1989; accepted 16 January 1989)

\begin{abstract}
Outer membranes were isolated from iron-limited and iron-sufficient Azomonas macrocytogenes ATCC 12334 by sucrose density centrifugation or treatment with Sarkosyl. Analysis of the outer membranes by sodium dodecyl sulphate polyacrylamide gel electrophoresis revealed that ironlimited cells produced greater amounts of two proteins of apparent molecular mass $74 \mathrm{kDa}$ and $70 \mathrm{kDa}$ than iron-sufficient cells. The enhanced production of these two proteins was evident when media contained less than $9 \cdot 7 \mu \mathrm{M}$ added iron with maximum production occurring when media contained less than $1.1 \mu \mathrm{M}$ added iron. Iron-limited growth conditions also caused $A$. macrocytogenes ATCC 12334 to excrete a visible yellow, blue-white fluorescent compound into culture supernatant fluids with maximum levels being produced in media that contained less than $1.1 \mu \mathrm{M}$ added iron. This fluorescent compound had a distinctive $\mathrm{pH}$-dependent absorption maximum characteristic of pyoverdin-type siderophores and appeared to bind iron. Furthermore, culture supernatant fluids containing the fluorescent compound promoted the uptake of ${ }^{55} \mathrm{Fe}$ in $A$. macrocytogenes ATCC 12334 cells. Three other $A$. macrocytogenes strains, NCIB 10958, NCIB 8700 and NCIB 9129, produced iron-repressible outer-membrane proteins but only the former two strains produced the iron-repressible fluorescent compound. It is proposed that the iron-regulated proteins and fluorescent compound produced by $A$. macrocytogenes may function in high-affinity iron uptake.
\end{abstract}

\section{INTRODUCTION}

Iron is an essential nutrient playing an important metabolic role in virtually all life forms so it is not surprising that iron regulates the expression of components of high-affinity iron uptake systems in various micro-organisms (Neilands, 1984). In response to iron limitation, Gramnegative micro-organisms synthesize iron-chelating compounds called siderophores and certain outer-membrane (OM) proteins (Neilands, 1981, 1982). In Escherichia coli these iron-regulated OM proteins function as ferrisiderophore receptors which mediate high-affinity iron uptake (Neilands, 1982). Many other Gram-negative organisms similarly express specific OM proteins in conjunction with the production of extracellular siderophores only when grown under iron limitation (Bachhawat \& Ghosh, 1987; De Weger et al., 1986; Hoe et al., 1985; Meyer et al., 1979; Page \& Huyer, 1984; Williams et al., 1984; Wright et al., 1986). These responses to iron limitation are also prevalent in pathogenic organisms grown in vivo (Brown et al., 1984; Griffiths, 1983) as well as in soil organisms grown in vitro with natural iron sources (Page \& Huyer, 1984). Therefore, high affinity iron uptake appears to be a universal strategy by which micro-organisms combat the extreme insolubility and unavailability of iron in their environment (Griffiths, 1983; Spiro \& Saltman, 1969).

Of the free-living, nitrogen-fixing Azotobacteraceae, Azotobacter vinelandii has been studied to an appreciable extent with respect to siderophore production (Page \& Huyer, 1984; Page \& von Tigerstrom, 1988) and iron-repressible OM proteins (Page \& von Tigerstrom, 1982) including

\footnotetext{
Abbreviations: DCPIP, 2,6-dichlorophenol-indophenol; 3,4-DHBA, 3,4-dihydroxybenzoic acid; OM protein, outer-membrane protein; Sarkosyl, $N$-lauroylsarcosine, sodium salt; SDS, sodium dodecyl sulphate.
} 
their presumed role in the mediation of high-affinity iron uptake (Knosp et al., 1984; Page \& Huyer, 1984). Also, iron-limited Azotobacter chroococcum strain 184 produces iron-repressible OM proteins and a putative hydroxamate siderophore (Page, 1987). Azomonas macrocytogenes, another member of the Azotobacteraceae, produces 3,4-dihydroxybenzoic acid (3,4-DHBA) (Collinson et al., 1987; Westervelt et al., 1985), an extracellular, low-affinity iron-binding compound that may play a role in solubilizing iron from the environment (Collinson et al., 1987). Evidence is accumulating that Azomonas macrocytogenes may also benefit from a high affinity iron uptake system. Several strains produce a blue-white fluorescent compound whose synthesis, unlike that of 3,4-DHBA (Collinson et al., 1987), is repressed by iron (Johnstone et al., 1958; Thompson \& Skerman, 1979). Moreover, Westervelt et al. (1985) isolated outer membranes from Azomonas macrocytogenes ATCC 12335 by Sarkosyl treatment and reported that this strain produced an iron-repressible protein with an apparent molecular mass of $83 \mathrm{kDa}$.

In view of the preliminary nature of these studies, we chose to undertake a detailed study of the effect of iron on the production of OM proteins and the fluorescent compound by the capsule-negative strain Azomonas macrocytogenes ATCC 12334. We found that iron-limited Azomonas macrocytogenes ATCC 12334 produced two OM proteins of $74 \mathrm{kDa}$ and $70 \mathrm{kDa}$ and a visible yellow, blue-white fluorescent compound which promoted ${ }^{55} \mathrm{Fe}$ uptake in these cells.

\section{METHODS}

Bacterial strains and growth conditions. Azomonas macrocytogenes strains ATCC 12334, NCIB 10958, NCIB 9129 and NCIB 8700 were grown in iron-, nitrogen-, and acetate-free liquid Burk medium (Page \& Sadoff, 1976) containing $1 \%(\mathrm{w} / \mathrm{v})$ mannitol (autoclaved separately). Where indicated, $1 \%(\mathrm{w} / \mathrm{v})$ glucose replaced mannitol and Burk medium was supplemented with $14 \mathrm{~mm}$-sodium acetate. To minimize extraneous iron contamination the distilled water was deionized and the glassware acid washed before use (Collinson et al., 1987). Iron-sufficient medium contained $\mathrm{FeSO}_{4}$ added as a sterile stock solution to a final concentration of $90 \mu \mathrm{M}$ unless otherwise specified. Liquid medium was inoculated from cultures grown on slants of nitrogen- and iron-sufficient Burk medium to an optical density at $620 \mathrm{~nm}\left(\mathrm{OD}_{620}\right)$ of approximately 0.05 as previously described (Collinson et al., 1987). Cultures of 200 or $400 \mathrm{ml}$ medium in 0.5 or 1 litre flasks, respectively, were incubated in the dark at $28-29^{\circ} \mathrm{C}$ on a gyratory shaker at 225 r.p.m. for $16 \mathrm{~h}$.

Isolation of outer and inner membranes. All manipulations were carried out at $0-4{ }^{\circ} \mathrm{C}$. Cells were harvested from a $400 \mathrm{ml}$ culture by centrifugation $(10000 \mathrm{~g}, 15 \mathrm{~min})$, washed twice with $10 \mathrm{mM}-\mathrm{Tris} / \mathrm{HCl}, \mathrm{pH} 7 \cdot 5$, then resuspended in the same buffer. The cells were broken by sonic disruption then treated for 60 min at room temperature $\left(22^{\circ} \mathrm{C}\right)$ with chicken egg white lysozyme $\left(0 \cdot 1 \mathrm{mg} \mathrm{ml}^{-1}\right.$, final concentration), DNAase and RNAase $\left(0.05 \mathrm{mg} \mathrm{ml}^{-1}\right.$, final concentration each) before the lysate was cleared of cellular debris by centrifugation $(12000 \mathrm{~g}, 10 \mathrm{~min})$. Outer membranes were separated from inner membranes in the cleared lysate by sucrose density centrifugation essentially as described by Page \& von Tigerstrom (1982). The crude membranes recovered from the two-step gradient were layered on a discontinuous sucrose gradient composed of $2 \mathrm{ml}$ each of $72,60,50,45,40 \%$ (w/v) sucrose in $10 \mathrm{~mm}$-Tris $/ \mathrm{HCl}$, pH 7.5, before centrifugation $(120000 \mathrm{~g}, 18 \mathrm{~h}$ ). Gradient fractions (approximately $0.4 \mathrm{ml}$ ) were collected by bottom puncture, analysed for sucrose concentration by refractometry, and stored at $-20^{\circ} \mathrm{C}$.

Alternatively, outer membranes were isolated from cleared cell lysate which had not been treated with lysozyme by selective solubilization of the inner membranes with $N$-lauroylsarcosine, sodium salt (Sarkosyl; Sigma) as previously described (Filip et al., 1973; Page \& Huyer, 1984). The final outer membrane pellet was resuspended in $0.1 \mathrm{ml} 8 \mathrm{~mm}$-Tris $/ \mathrm{HCl}, \mathrm{pH} 7.5$, containing $0.1 \%$ (w/v) sodium dodecyl sulphate (SDS) before storage at $-20^{\circ} \mathrm{C}$.

Sodium dodecyl sulphate polyacrylamide gel electrophoresis. SDS-PAGE was performed essentially as described by Laemmli (1970). However, the stacking and separating gels were polymerized using $0 \cdot 1 \%(\mathrm{v} / \mathrm{v})$ and $0.067 \%$ (v/v) $N, N, N^{\prime}, N^{\prime}$-tetramethylethylenediamine (Eastman Kodak), respectively, and $0.05 \%(\mathrm{w} / \mathrm{v})$ ammonium persulphate. Samples were boiled for $5 \mathrm{~min}$ in sample buffer (Bingle et al., 1984) and applied to gels prior to electrophoresis. Protein- and carbohydrate-containing material in the polyacrylamide gels was stained with Coomassie brilliant blue-R (Sigma) and Schiff reagent, respectively, according to Fairbanks et al. (1971).

Succinate dehydrogenase assay. Succinate dehydrogenase activity was assayed by a modification of the method of Ells (1959) and Kasahara \& Anraku (1974). The reaction mixture contained 50mm-Tris/HCl, pH 7.5, 4 mMKCN (freshly prepared), $20 \mathrm{~mm}$-sodium succinate, $0.053 \mathrm{~mm}$-2,6-dichlorophenol-indophenol (DCPIP, Sigma), $0 \cdot 2$ mM-phenazine methosulphate (Sigma), and approximateiy $5 \mu \mathrm{g}$ protein from the sucrose gradient fractions. The decrease in absorbance at $600 \mathrm{~nm}$ was monitored in a Perkin-Elmer Lambda 3 spectrophotometer for 8 min. The molar absorption coefficient for DCPIP $\left(2.16 \times 10^{4} 1 \mathrm{~mol}^{-1} \mathrm{~cm}^{-1}\right)$ was calculated according to the formula provided by Armstrong (1964) for $\mathrm{pH} 7 \cdot 6$, the $\mathrm{pH}$ of the assay mixture. The average specific activity of succinate dehydrogenase [nmol DCPIP reduced $\min ^{-1}$ (mg protein $)^{-1}$ ] was calculated from duplicate assays. 
Protein determinations. Protein was quantified by the method of Lowry using bovine serum albumin (Sigma) as a standard. Samples of protein from the sucrose gradient fractions or Sarkosyl preparations were assayed directly but sucrose, Tris buffer, and SDS were incorporated into standard curves as required to compensate for the interference of these compounds (Gerhardt \& Beevers, 1968).

To determine the total cell protein in cultures, cell pellets recovered from a known volume of cell culture $(1640 \mathrm{~g}$, $15 \mathrm{~min}$ ) were digested in $0 \cdot 1 \mathrm{M}-\mathrm{NaOH}$ at $90^{\circ} \mathrm{C}$ for $1 \mathrm{~h}$. After removal of the cellular debris $(1640 \mathrm{~g}, 15 \mathrm{~min})$ the supernatant was assayed for protein.

Detection and analysis of the fluorescent compound. Cell-free culture supernatant fluids were obtained by removal of the cells by centrifugation $(10000 \mathrm{~g}, 15 \mathrm{~min})$ followed by filter sterilization of the supernatant fluids $(0.45 \mu \mathrm{m}$ pore size, Millipore). The fluorescent compound was readily detected in cell-free culture supernatant fluids by illumination with UV light at $366 \mathrm{~nm}$. Absorption spectra of cell-free culture supernatant fluids were recorded using a Perkin-Elmer Lambda 3 spectrophotometer. To quantify the fluorescent compound, cell-free culture supernatants were adjusted to $\mathrm{pH} 5$ with pyridine/acetic acid buffer $(0.05 \mathrm{M}$, final concentration) and the absorbance measured at $380 \mathrm{~nm}\left(A_{380}\right)$.

${ }^{55}$ Iron uptake assay conditions. ${ }^{55} \mathrm{Fe}$ uptake assays were performed essentially as described by Knosp et al. (1984) with the following modifications. Cells grown for $16 \mathrm{~h}$ in iron-limited or iron-sufficient medium were harvested by centrifugation $\left(10000 \mathrm{~g}, 15 \mathrm{~min}, 4^{\circ} \mathrm{C}\right)$ and resuspended in $10 \mathrm{ml}$ iron-, nitrogen-, and acetate-free liquid Burk medium containing $0.5 \%(\mathrm{w} / \mathrm{v})$ mannitol and $10 \mathrm{~mm}$-trisodium citrate (uptake buffer). The cells were layered on a $20 \mathrm{ml}$ Percoll (Pharmacia LKB) cushion composed of Percoll $/ 0 \cdot 15 \mathrm{M}-\mathrm{NaCl}(2: 1, \mathrm{v} / \mathrm{v})$, and centrifuged $(12000 \mathrm{~g}$, $10 \mathrm{~min}, 4^{\circ} \mathrm{C}$ ). Both iron-limited and iron-sufficient cells were subjected to this step; however, it was done mainly to separate insoluble iron salts from the iron-sufficient cells. The insoluble iron salts were presumably in the form of ferric hydroxide and ferric phosphate which would be expected to form under culture conditions of neutral $\mathrm{pH}$ and high aeration (Spiro \& Saltman, 1969; Greenwood \& Earnshaw, 1984). Cells recovered from the top of the Percoll cushion were washed twice in $20 \mathrm{ml}$ uptake buffer and the final cell pellet resuspended to $\mathrm{OD}_{620}$ of approximately 9 , from which samples were taken for viable cell counts and protein determinations. The resuspended cells were diluted to an $\mathrm{OD}_{620}$ of approximately 3 in the appropriate uptake solution and held on ice until required for the ${ }^{55} \mathrm{Fe}$ uptake assays.

Uptake solutions consisted of uptake buffer or filter-sterilized culture supernatant fluids recovered from $16 \mathrm{~h}$ cultures. Iron-sufficient culture supernatants were made to $0.5 \%(\mathrm{w} / \mathrm{v})$ mannitol and $10 \mathrm{~mm}$-trisodium citrate then diluted with an equal volume of uptake buffer. Iron-limited culture supernatant fluids, used as a source of the fluorescent compound, were similarly supplemented with mannitol and trisodium citrate then diluted with an equal volume of uptake buffer or undiluted, supplemented iron-sufficient supernatant giving a final $A_{380}$ of approximately $0 \cdot 05$. The $\mathrm{pH}$ of the uptake solutions ranged from 6.9-7.4.

Uptake solutions were incubated $\left(25^{\circ} \mathrm{C}, 225\right.$ r.p.m., $\left.1.5 \mathrm{~h}\right)$ with ${ }^{55} \mathrm{FeCl}_{3}$ (Amersham) added to a concentration of $0.5 \mu \mathrm{Ci} \mathrm{m}^{-1}\left(18.5 \mathrm{kBq} \mathrm{ml}^{-1}\right)$ and $5 \mu \mathrm{M}-\mathrm{Fe}^{3+}$ to allow equilibration of the ${ }^{55} \mathrm{Fe}$ with the uptake solutions. Five minutes prior to the start of the assay, the cell suspensions and the preincubated uptake solutions were placed at $25{ }^{\circ} \mathrm{C}$ (test) or $0{ }^{\circ} \mathrm{C}$ (control) at 225 r.p.m. To start the assay, a volume of the cell suspension was added to an equal

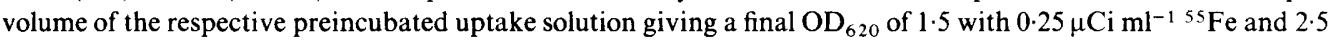
$\mu \mathrm{M}-\mathrm{Fe}^{3+}$. These solutions were incubated at the appropriate temperature, duplicate samples $(0.5 \mathrm{ml})$ withdrawn at the indicated times, cells collected by rapid filtration, and the amount of the cell-associated ${ }^{55} \mathrm{Fe}$ determined by liquid scintillation counting as previously described (Knosp et al., 1984) using a Beckman LS3801 liquid scintillation counter. Standards for counting efficiency were made by placing a known amount of ${ }^{55} \mathrm{Fe}$ onto a dried filter on which cells from $0.5 \mathrm{ml}$ of a cell suspension $\mathrm{OD}_{620} 1.5$ had been collected. The amount of the ${ }^{55} \mathrm{Fe}$ present was determined by liquid scintillation counting as above. The counting efficiency was generally found to be $27-$ $30 \%$.

Iron determinations. Iron-limited growth medium was reduced to near dryness (Büchi Rotavapor-R), then resuspended in $1.6 \mathrm{M}-\mathrm{HCl}$ to give a 10 -fold concentrated medium. This concentrated medium was analysed in an atomic absorption spectrophotometer (Instrumentation Laboratory spectrophotometer $75 \mathrm{l}$ ) using $\mathrm{FeCl}_{3}$ in $1.6 \mathrm{M}$ $\mathrm{HCl}$ as a standard. All glassware was acid washed.

To confirm the amount of iron added to growth media, the concentration of iron in a freshly prepared, filtersterilized stock solution of $\mathrm{FeSO}_{4}$ was determined using 2,2'-dipyridyl (Collinson et al., 1987).

\section{RESULTS}

Isolation of outer and inner membranes from Azomonas macrocytogenes ATCC 12334 by sucrose density centrifugation

Sucrose gradient density centrifugation of Azomonas macrocytogenes ATCC 12334 crude membrane preparations resulted in two peaks of buoyant density $1.26(\mathrm{H})$ and $1.14(\mathrm{~L})$, each 


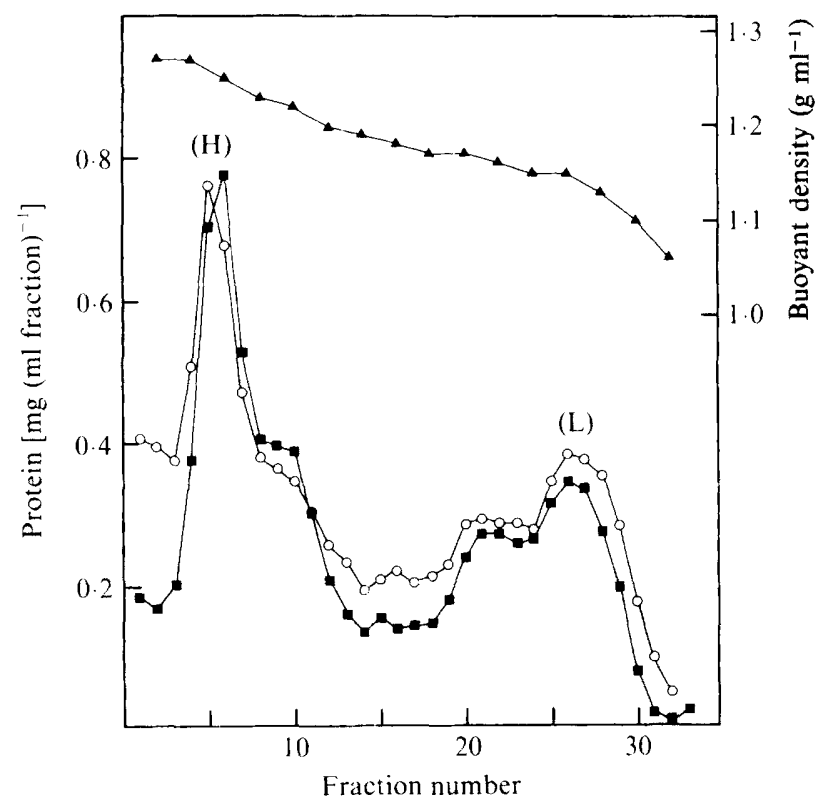

Fig. 1. Separation of crude membranes isolated from Azomonas macrocytogenes ATCC 12334 by sucrose density centrifugation. Membranes were isolated from cells grown in iron-limited $(O)$ or iron-sufficient medium ( $\mathbf{C})$ and subjected to sucrose density centrifugation. $(\mathrm{H})$ high density peak; (L) low density peak. Data from a typical gradient are presented.

with a shoulder, of buoyant density 1.22 and $1 \cdot 16$, respectively (Fig. 1). This was consistent with the separation of outer and inner membranes of other Gram-negative bacteria (Bachhawat \& Ghosh, 1987; Mizuno \& Kageyama, 1978; Osborn et al., 1972; Schnaitman, 1970). Similar results were obtained when crude membranes were isolated from cells grown in iron-sufficient or iron-limited media (Fig. 1).

SDS-PAGE analysis of the high-density peak $(\mathrm{H})$ revealed a protein profile consisting of a few major proteins and some minor protein bands typical of Gram-negative outer membrane (Lugtenberg \& van Alphen, 1983) (Fig. 2a). Conversely, electrophoresis of proteins from the low density peak (L) showed an array of bands typical of inner membrane protein profiles of Gramnegative bacteria (Fig. $2 a$ ). The $\mathrm{H}$ peak did not appear appreciably contaminated with proteins from the $\mathrm{L}$ peak. Furthermore, the $\mathrm{H}$ peak contained material reactive with the Schiff reagent following periodate oxidation, which indicated the presence of carbohydrate material, probably from lipopolysaccharide (Fig. $2 b$ ). The slight amount of Schiff-positive material present in the L peak implied minor contamination of this peak with material from the $\mathrm{H}$ peak. The minor peaks between $\mathrm{H}$ and $\mathrm{L}$ had protein profiles similar to that of the adjacent main peak (data not shown). This general distribution of proteins and carbohydrates in the $\mathrm{H}$ and $\mathrm{L}$ peaks was seen when membranes were recovered from cells grown in iron-limited or iron-sufficient medium.

The succinate dehydrogenase specific activity of the $L$ peak isolated from iron-limited and iron-sufficient cells was 105 and $718 \mathrm{nmol} \mathrm{DCPIP}$ min $^{-1}$ (mg protein $)^{-1}$, respectively, compared to 26 and $74 \mathrm{nmol}$ DCPIP $\min ^{-1}$ (mg protein) ${ }^{-1}$ for the $\mathrm{H}$ peak. This lower succinate dehydrogenase activity for the $\mathrm{H}$ peak was not due to inhibition of enzyme activity by the higher levels of sucrose in these fractions (Hinton et al., 1969) since supplementation of the L peak with sucrose to equivalent levels found in the $\mathrm{H}$ peak did not significantly lower the enzyme activity. These results indicated that the $\mathrm{H}$ peak was outer membrane and was separated from the $\mathrm{L}$ peak which was inner membrane, albeit with some residual inner membrane contamination of the outer membrane.

The succinate dehydrogenase specific activity of cytoplasmic membrane recovered from ironlimited cells was seven-fold lower than that of iron-sufficient cells. While this observation is 

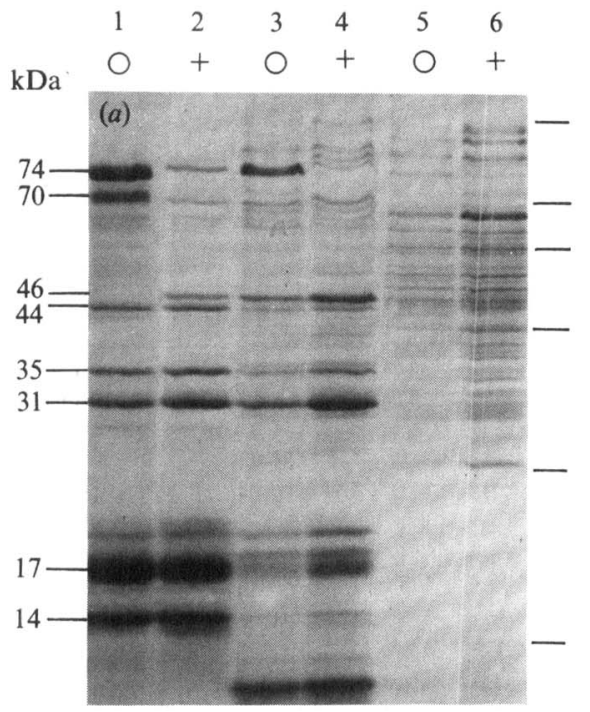

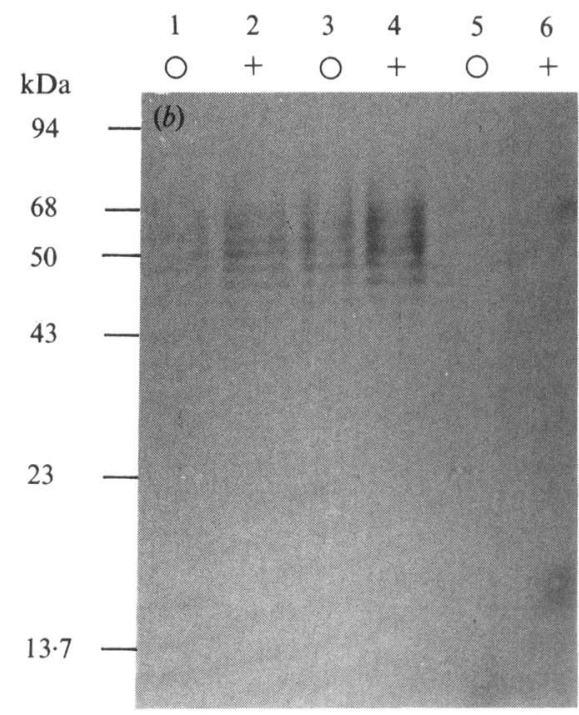

Fig. 2. SDS-PAGE of outer membranes isolated from iron-limited $(O)$ or iron-sufficient $(+)$ Azomonas macrocytogenes ATCC 12334 isolated by sucrose density centrifugation or treatment with Sarkosyl. Two $12 \%$ polyacrylamide gels were loaded with samples from Sarkosyl-treated outer membranes (lanes 1,2 ); fraction 5 of the $\mathrm{H}$ peak (lanes 3,4); or fraction 26 of the $\mathrm{L}$ peak (lanes 5,6). Each lane received 15 $\mu \mathrm{g}$ protein. One gel was stained for protein with Coomassie blue-R $(a)$, and the other gel was stained for carbohydrate with Schiff reagent $(b)$. The following proteins (Sigma) were used as standards: phosphorylase $a(94 \mathrm{kDa})$, bovine serum albumin $(68 \mathrm{kDa})$, gamma globulin II $\mathrm{H}$ chain $(50 \mathrm{kDa})$, ovalbumin $(43 \mathrm{kDa})$, gamma globulin II L chain $(23 \mathrm{kDa})$, ribonuclease A (13.7 kDa).

likely a result of the severe iron stress experienced by iron-limited Azomonas macrocytogenes ATCC 12334, as has been observed in other iron-stressed micro-organisms (Healy et al., 1955; Winder \& O'Hara, 1964), it is not known whether this lower activity reflects a lack of iron in the iron-requiring succinate dehydrogenase enzyme or a decreased level of enzyme production due to the iron starved status of these cells.

\section{Comparison of OM proteins isolated by sucrose density centrifugation and by Sarkosyl treatment}

Since OM proteins of Azomonas macrocytogenes have been previously isolated by Sarkosyl treatment of cells recovered from solid media (Westervelt et al., 1985), we decided to compare the reliability of this simple extraction method to the physical separation of inner membrane from outer membrane by sucrose density centrifugation. OM proteins recovered by Sarkosyl extraction from Azomonas macrocytogenes ATCC 12334 cells grown with or without iron gave SDS-PAGE profiles that differed from the respective sucrose gradient preparations (Fig. $2 a$ ). Firstly, a front-running protein seen in the SDS-PAGE of outer membrane isolated by sucrose density centrifugation but not by Sarkosyl treatment was probably lysozyme as this protein had the same mobility as an authentic lysozyme standard. Also, there is a precedent for lysozyme binding to membrane preparations of other Gram-negative bacteria (Mizuno \& Kageyama, 1978; Osborn et al., 1972). Secondly, the apparent ratios of some of the proteins varied depending on the method used to isolate the outer membrane. Except for the $31 \mathrm{kDa}$ and $46 \mathrm{kDa}$ OM proteins, the major OM proteins were present in higher amounts in Sarkosyl preparations compared to the proteins of the same molecular mass seen on SDS-PAGE of outer membrane isolated by sucrose density centrifugation. In the case of the $70 \mathrm{kDa}$ protein from iron-limited cells, or $14 \mathrm{kDa}$ protein from both cell types, only trace amounts were found in sucrose density centrifugation preparations. Conversely, the $46 \mathrm{kDa}$ protein was lacking in outer membrane prepared from Sarkosyl preparations of iron-limited cells. Finally, the SDS-PAGE of OM proteins isolated by treatment with Sarkosyl lacked some of the minor proteins seen in the SDSPAGE of OM proteins isolated by sucrose density centrifugation. This probably reflected the 
slight contamination of outer membrane with inner membrane in the sucrose preparations and the possible extraction of some minor proteins from the outer membrane by Sarkosyl as has been noted in $E$. coli (Chopra \& Shales, 1980). In spite of the few differences mentioned, Sarkosyl treatment resulted in isolation of outer membrane from Azomonas macrocytogenes ATCC 12334.

\section{Iron-regulated OM proteins of Azomonas macrocytogenes ATCC 12334}

Two proteins, $74 \mathrm{kDa}$ and $70 \mathrm{kDa}$, were produced in greater amounts in the outer membrane of iron-limited rather than iron-sufficient Azomonas macrocytogenes ATCC 12334 (Fig. 2a). Whether cells were grown with $1 \%(\mathrm{w} / \mathrm{v})$ glucose or mannitol with or without $14 \mathrm{~mm}$-acetate the $74 \mathrm{kDa}$ and $70 \mathrm{kDa}$ proteins were consistently present in outer membrane isolated by Sarkosyl extraction as long as the cultures were iron-limited (data not shown). The $74 \mathrm{kDa}$ ironrepressible OM protein was present when outer membrane was prepared by sucrose density centrifugation but the $70 \mathrm{kDa}$ iron-repressible protein was not usually visible in these preparations. SDS-PAGE of various fractions taken from several regions of the sucrose gradient did not reveal the enhanced production of proteins of either mobility in any other part of the sucrose gradient (data not shown).

\section{Production of an iron-binding fluorescent compound by Azomonas macrocytogenes ATCC 12334}

Iron-limited Azomonas macrocytogenes ATCC 12334 excreted a visible yellow, strongly bluewhite fluorescent compound into the culture supernatant fluid which was completely repressed in cells grown in iron-sufficient media (Fig. $3 a$ ). The amount of the fluorescent compound produced was greater if mannitol was the carbon source rather than glucose even though media supplemented with either sugar contained similar levels of contaminating iron as determined by atomic absorption spectroscopy. Iron-limited cultures grown for $20 \mathrm{~h}$ with $1 \%(\mathrm{w} / \mathrm{v})$ mannitol produced levels of the fluorescent compound corresponding to $A_{380}$ of $0.25-0.36$ and reached an $\mathrm{OD}_{620}$ of $0 \cdot 32-0 \cdot 34$. The substitution of glucose for mannitol in these cultures resulted in low production of the fluorescent compound $\left(A_{380} \quad 0.03-0.04\right)$ even though cultures reached an $\mathrm{OD}_{620}$ of $0 \cdot 22-0 \cdot 28$. Similar results were obtained if the cultures containing mannitol or glucose were also supplemented with $14 \mathrm{~mm}$-sodium acetate. Furthermore, cultures grown for $24 \mathrm{~h}$ with $1 \%(\mathrm{w} / \mathrm{v})$ glucose and $14 \mathrm{~mm}$-sodium acetate with reduced aeration (176 r.p.m.) (Collinson et al., 1987) produced lower levels of the fluorescent compound ( $\left.A_{380} 0 \cdot 02-0 \cdot 13 ; \mathrm{OD}_{620} 0 \cdot 15-0 \cdot 28\right)$ compared to similar cultures where mannitol replaced glucose $\left(A_{380} 0 \cdot 20-0 \cdot 34 ; \mathrm{OD}_{620} 0.27-\right.$ $0 \cdot 34)$.

All cultures containing glucose became $\mathrm{pH} 5$ or less after $24 \mathrm{~h}$ growth, and although the cells remained viable, further production of the fluorescent compound did not occur. Cells cultured in the presence of mannitol, however, rarely acidified the medium below pH 6 and continued producing the fluorescent compound (Fig. $3 a$ ). A characteristic shift in the visible spectrum of the fluorescent compound was seen when the $\mathrm{pH}$ of the culture supernatant fluids was adjusted (Fig. $3 b$ ). Moreover, when $\mathrm{FeCl}_{3}$ was added to the supernatants buffered at $\mathrm{pH}$, the fluid turned brown, the absorption maximum shifted to $400 \mathrm{~nm}$, and a broad shoulder appeared near $450 \mathrm{~nm}$ (Fig. $3 c$ ).

\section{Iron-regulated production of OM proteins and the fuorescent compound by Azomonas macrocytogenes}

Azomonas macrocytogenes ATCC 12334 was grown for $16 \mathrm{~h}$ in media containing decreased amounts of iron. SDS-PAGE of outer membranes isolated from these cells indicated that production of the $74 \mathrm{kDa}$ and $70 \mathrm{kDa}$ proteins was slightly increased when media contained less than $9 \cdot 7 \mu \mathrm{M}$ added iron and was at a maximum when cultures contained less than $1 \cdot 1 \mu \mathrm{M}$ added iron (Fig. 4). Similarly, production of the blue-white fluorescent compound by Azomonas macrocytogenes ATCC 12334 increased in culture supernatant fluids as a result of decreased iron availability and became maximal in medium containing less than $1 \cdot 1 \mu \mathrm{M}$ added iron (Fig. 5). The finat $\mathrm{pH}$ of these cultures was $6 \cdot 2-6 \cdot 3$. Coincident with enhanced production of the two OM proteins and the blue-white fluorescent compound, was restricted growth of cells when media contained less than $9.7 \mu \mathrm{M}$ added iron (Fig. 5). The growth that occurred in cultures without 

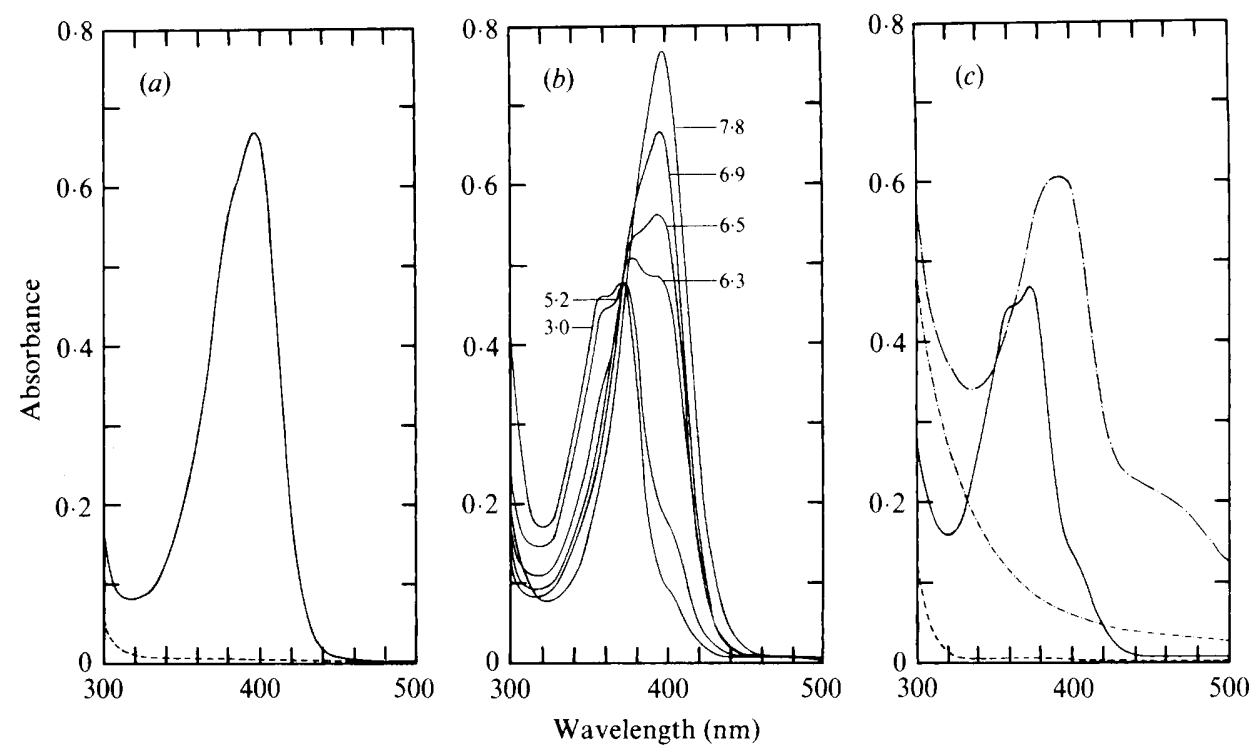

Fig. 3. Absorption spectra of filter-sterilized culture supernatant fluids of Azomonas macrocytogenes ATCC 12334 grown in iron-limited $(-$ ) or iron-sufficient $(---)$ Burk medium for $38 \mathrm{~h}$. (a) Ironlimited and iron-sufficient supernatants were diluted with an equal volume of distilled $\mathrm{H}_{2} \mathrm{O}$ and the $\mathrm{pH}$ determined to be 6.9 and $6 \cdot 2$, respectively. (b) The iron-limited culture supernatant fluid from $(a)$ was diluted in an equal volume of distilled $\mathrm{H}_{2} \mathrm{O}$, the $\mathrm{pH}$ adjusted with concentrated $\mathrm{HCl}$ or $\mathrm{NaOH}$, and the spectrum recorded. The total volume change of the adjusted fluids was less than $0.2 \%$. The $\mathrm{pH}$ of each supernatant is noted in the figure. (c) Culture supernatant fluids from $(a)$ were adjusted to $\mathrm{pH} 5$ with an equal volume of $0 \cdot 1 \mathrm{M}$-pyridine/acetic acid buffer and the spectrum of the iron-limited supernatant ( - ) and the iron-sufficient supernatant (-- ) was recorded. Then $\mathrm{FeCl}_{3}$ was added to each supernatant $(0.1 \mathrm{mM}$, final concentration) and the spectrum of the iron-limited (.-.-.) and ironsufficient supernatants (-.-.) were recorded. The volume change by adding the iron was less than $0 \cdot 2 \%$.

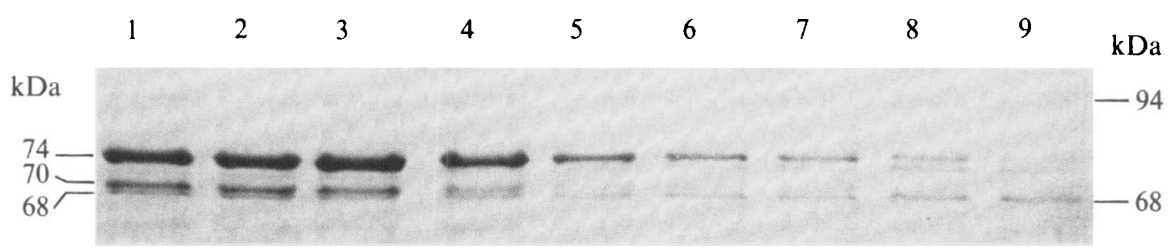

Fig. 4. High-molecular mass OM proteins of Azomonas macrocytogenes ATCC 12334 isolated from cells grown in Burk medium containing the following concentrations of iron added as $\mathrm{FeSO}_{4}$ : no added iron (lane 1);0.02 $\mu \mathrm{M}$ (lane 2); $0.2 \mu \mathrm{M}$ (lane 3); $1.1 \mu \mathrm{M}$ (lane 4); $2.3 \mu \mathrm{M}$ (lane 5); $9.7 \mu \mathrm{M}$ (lane 6); $19 \mu \mathrm{M}$ (lane 7); $95 \mu \mathrm{M}$ (lane 8 ); $185 \mu \mathrm{M}$ (lane 9 ). The $10 \%$ polyacrylamide gel was loaded with $10 \mu \mathrm{g}$ protein per well. Standard proteins were the same as for Fig. 2.

added iron was a result of contamination of the iron-limited medium with approximately $0.5 \mu \mathrm{M}$ iron as determined by atomic absorption spectroscopy. Also, cells in the initial inoculum were iron-sufficient as indicated by the lack of the $74 \mathrm{kDa}$ and $70 \mathrm{kDa}$ proteins in their outer membranes and their failure to produce the fluorescent compound (data not shown).

\section{${ }^{55}$ Iron uptake by Azomonas macrocytogenes ATCC 12334}

${ }^{55}$ Iron uptake by iron-limited Azomonas macrocytogenes ATCC 12334 cells at $25^{\circ} \mathrm{C}$ was greatly enhanced only when uptake solutions contained the fluorescent compound (Fig. $6 a$ ). The rate of ${ }^{55} \mathrm{Fe}$ uptake by cells resuspended in iron-sufficient supernatant fluid was not lower due to a significant dilution of the ${ }^{55} \mathrm{Fe}$ specific activity by residual iron in this supernatant. Ironlimited supernatant diluted with an equal volume of iron-sufficient supernatant promoted 


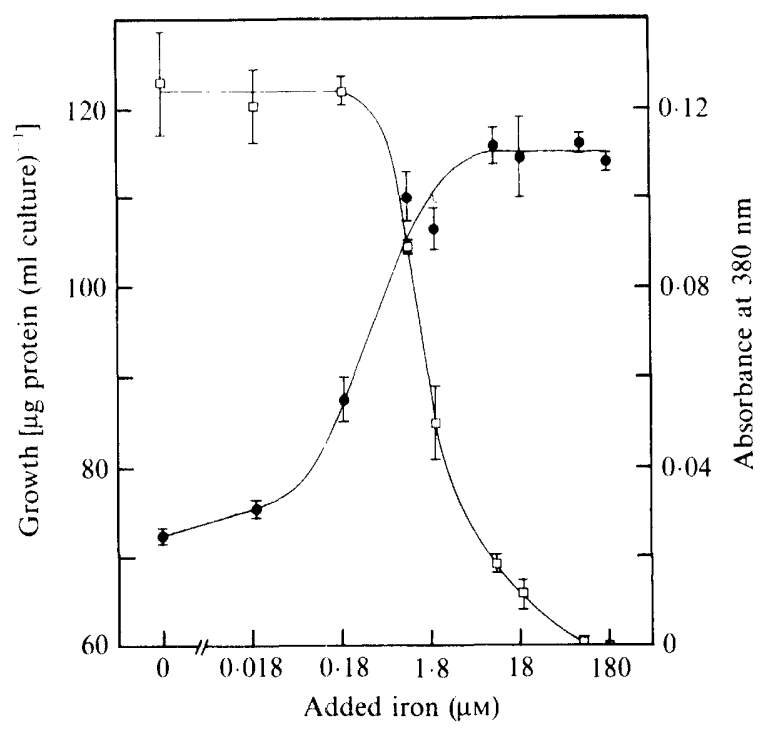

Fig. 5. Azomonas macrocytogenes ATCC 12334 was grown for $16 \mathrm{~h}$ in Burk medium containing various amounts of iron added as $\mathrm{FeSO}_{4}$. The total cellular protein $(\boldsymbol{O})$, and the absorbance of the cell-free culture supernatant fluid at $380 \mathrm{~nm}(\square)$ were recorded. Each value represents the mean from duplicate cultures. Error bars indicate the range of values for each determination.
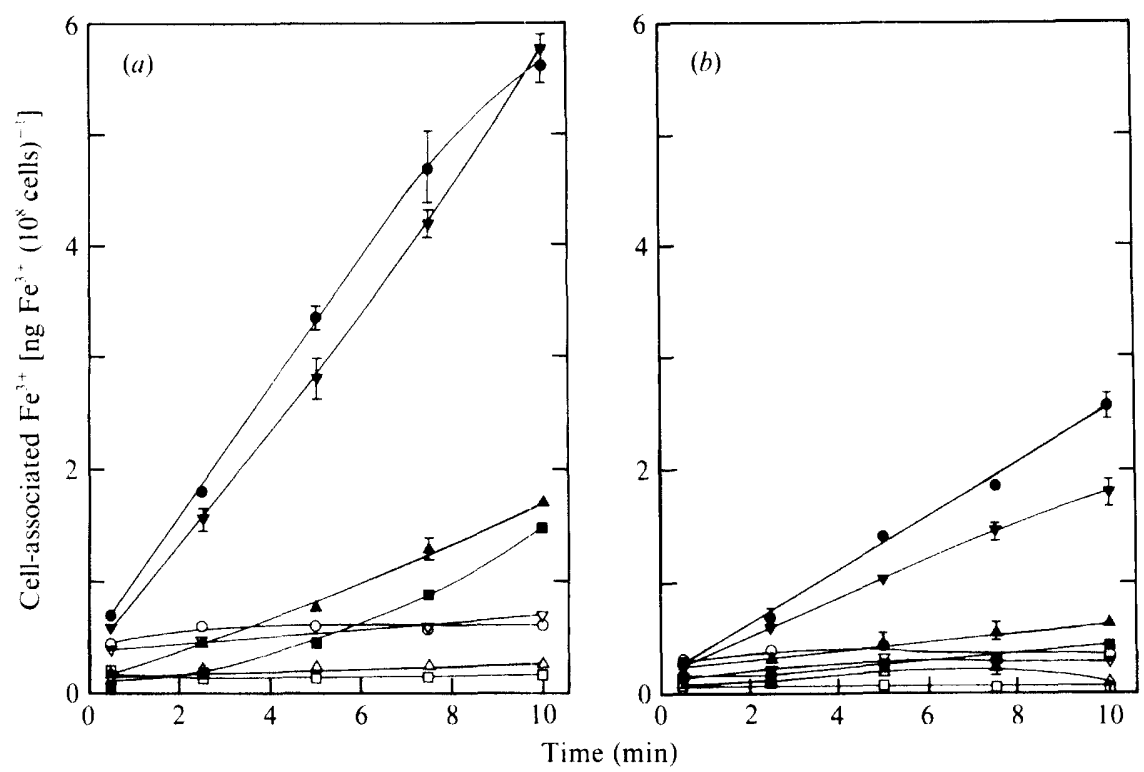

Fig. 6. Uptake of ${ }^{55} \mathrm{Fe}$ by Azomonas macrocytogenes ATCC 12334. (a) Iron-limited cells were assayed for ${ }^{55} \mathrm{Fe}$ uptake at $25^{\circ} \mathrm{C}$ (filled symbols) or $0{ }^{\circ} \mathrm{C}$ (open symbols) after resuspension in the following uptake solutions: uptake buffer $(\square, \square)$; iron-limited culture supernatant supplemented with $0 \cdot 5 \%$ $(\mathrm{w} / \mathrm{v})$ mannitol and $10 \mathrm{~mm}$-trisodium citrate then diluted with an equal volume of uptake buffer $(0,0)$; iron-sufficient culture supernatant supplemented with $0.5 \%$ mannitol and $10 \mathrm{~mm}$-trisodium citrate then diluted with an equal volume of uptake buffer $(\boldsymbol{\Lambda}, \triangle)$; or a $1: 1$ dilution $(\mathbf{v} / \mathbf{v})$ of iron-limited culture supernatant with iron-sufficient culture supernatant both supplemented with $0.5 \%$ mannitol and 10 mM-trisodium citrate $(\boldsymbol{\nabla}, \nabla)$. (b) Iron-sufficient cells were assayed for ${ }^{55} \mathrm{Fe}$ uptake at $25^{\circ} \mathrm{C}$ (closed symbols) or $0{ }^{\circ} \mathrm{C}$ (open symbols) as for iron-limited cells. Symbols for uptake solutions as for $(a)$. Error bars indicate when the range of duplicate samples exceeded $0 \cdot 1 \mathrm{ng} \mathrm{Fe}^{3+}\left(10^{8} \text { cells }\right)^{-1}$. 
similar, albeit slightly lower, ${ }^{55} \mathrm{Fe}$ uptake rates in iron-limited cells as iron-limited supernatant diluted with uptake buffer (Fig. $6 a$ ). It is likely that the rate of ${ }^{55} \mathrm{Fe}$ uptake by iron-limited cells resuspended in iron-sufficient supernatant or uptake buffer was due to endogenous production of the fluorescent compound by the iron-limited cells. These cells were typically very fluorescent and despite washing of the cells prior to resuspension in uptake buffer, the fluorescent compound was released at levels of $A_{380} 0.013-0.020$ when the cells were held on ice. When these cells were incubated at $25^{\circ} \mathrm{C}$ for $50 \mathrm{~min}$, the $A_{380}$ increased linearly to 0.055 . The possibility of citrate-promoted ${ }^{55} \mathrm{Fe}$ uptake in these cells was not ruled out and attempts to use other potentially inert chelators such as nitrilotriacetate or ethylenediamine di-(o-hydroxyphenylacetic acid) at $1.4 \mathrm{~mm}$ or $10 \mu \mathrm{M}$, respectively, to keep the iron soluble in this assay system resulted in unacceptably high backgrounds even when no cells were present in the assay system. ${ }^{55} \mathrm{Fe}$ associated with iron-limited cells assayed at $0{ }^{\circ} \mathrm{C}$ was not due to non-specific binding of ${ }^{55} \mathrm{Fe}$ to the filters since the ${ }^{55} \mathrm{Fe}$ collected on filters from $0.5 \mathrm{ml}$ samples without cells was 2 - to 10 -fold less than samples containing cells (data not shown). Iron-limited cells assayed at $0{ }^{\circ} \mathrm{C}$ in the presence of the fluorescent compound bound approximately $2 \cdot 5$-fold more iron than cells similarly assayed in the absence of the fluorescent compound (Fig. $6 a$ ). Since this binding of iron was almost complete in $0.5 \mathrm{~min}$, it probably represented adventitious binding of iron to the surface of these cells.

The pattern of ${ }^{55} \mathrm{Fe}$ uptake rates by iron-sufficient cells suspended in the various uptake solutions was similar to the iron-limited cells but the respective rates were 2- to 4-5-fold less over the $10 \mathrm{~min}$ assay period than iron-limited cells assayed under identical conditions (Fig. 6b).

\section{Effect of iron on the production of $O M$ proteins and the fluorescent compound by various Azomonas macrocytogenes strains}

Outer membranes of various strains of Azomonas macrocytogenes were isolated by treatment of cell lysates with Sarkosyl and the proteins analysed by SDS-PAGE to compare their OM protein profile to that of Azomonas macrocytogenes ATCC 12334. While Azomonas macrocytogenes strains NCIB 10958 and NCIB 8700 exhibited iron-repressible OM proteins analogous to those of ATCC 12334, strain NCIB 9129 did not produce the $74 \mathrm{kDa}$ ironrepressible OM protein to the same extent as the other strains (Fig. 7). Strain NCIB 9129 produced an additional iron-repressible OM protein of $77 \mathrm{kDa}$ (Fig. 7, lane 5). Like strain ATCC 12334, both NCIB 10958 and NCIB 8700 produced a blue-white fluorescent compound under iron-limited conditions; however, iron-limited NCIB 9129 failed to produce this compound.

\section{DISCUSSION}

We investigated the possible existence of a high-affinity iron uptake system in Azomonas macrocytogenes. The characterization of the $\mathrm{OM}$ proteins and an extracellular fluorescent compound produced by iron-limited Azomonas macrocytogenes ATCC 12334 provided evidence that implicated these molecules as functional components of a high-affinity iron uptake system in this organism.

Isolation of outer membranes from Azomonas macrocytogenes ATCC 12334 by Sarkosyl treatment of cell lysates resulted in a typical Gram-negative OM profile on SDS-PAGE as confirmed by preparations of outer membranes by sucrose density centrifugation. Azomonas macrocytogenes ATCC 12334 produced two OM proteins of $74 \mathrm{kDa}$ and $70 \mathrm{kDa}$ when grown in iron-limited but not iron-sufficient media. The minor differences seen in SDS-PAGE profile of OM proteins prepared by Sarkosyl extraction or sucrose density centrifugation was not surprising considering the different techniques involved, but it was unexpected to note the absence of the major, iron-regulated $70 \mathrm{kDa}$ protein in sucrose gradient preparations. The reason for this is not clear but may be explained if this protein were associated with peptidoglycan as is the FhuA iron-repressible OM protein of E. coli (Menichi \& Buu, 1986). Detailed experimentation of the physiology of Azomonas macrocytogenes ATCC 12334 outer membranes will be required to clarify this point; however, it is important to note that the 


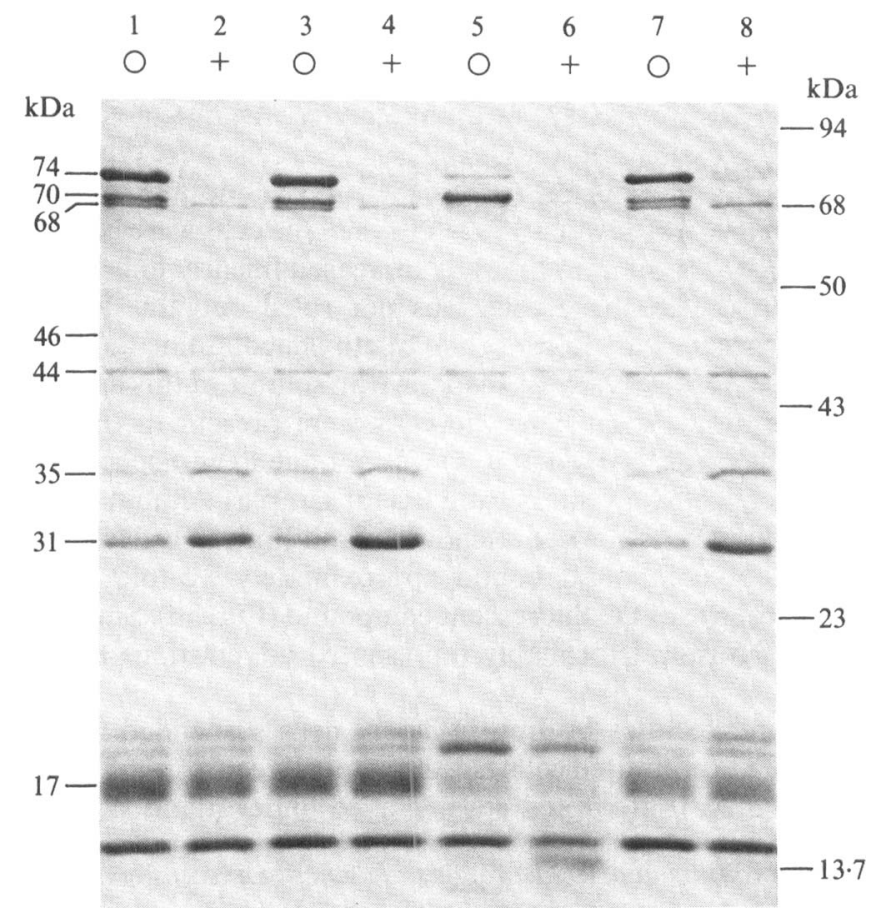

Fig. 7. SDS-PAGE of OM proteins isolated from various strains of Azomonas macrocytogenes by Sarkosyl extraction. Outer membranes were isolated from strains ATCC 12334 (lanes 1, 2), NCIB 8700 (lanes 3,4), NCIB 9129 (lanes 5,6), and NCIB 10958 (lane 7, 8) grown in iron-limited (O) or ironsufficient $(+)$ medium. The $10 \%$ polyacrylamide gel was loaded with $10 \mu \mathrm{g}$ protein per well. Standard proteins were the same as for Fig. 2.

presence of the $70 \mathrm{kDa}$ iron-repressible $\mathrm{OM}$ protein is dependent on the procedure used to isolate outer membranes.

Production of high-molecular-mass, iron-repressible OM proteins is not peculiar to Azomonas macrocytogenes ATCC 12334 since two other strains, NCIB 10958 and NCIB 8700, produced 74 $\mathrm{kDa}$ and $70 \mathrm{kDa}$ OM proteins when grown under iron-limited conditions. Iron-limited NCIB 9129 failed to produce the $74 \mathrm{kDa}$ iron-repressible OM protein to the extent of that produced by the other strains, but it did produce a $70 \mathrm{kDa}$ as well as a $77 \mathrm{kDa}$ iron-repressible OM protein. In our hands none of the strains produced an iron-regulated OM protein of $83 \mathrm{kDa}$ as was previously isolated from iron-limited Azomonas macrocytogenes ATCC 12335 (same strain as NCIB 8700) (Westervelt et al., 1985).

The $74 \mathrm{kDa}$ and $70 \mathrm{kDa}$ OM proteins produced by iron-limited Azomonas macrocytogenes ATCC 12334 are possible ferrisiderophore receptor proteins. The iron-regulated production of these two proteins and their molecular mass was similar to ferrisiderophore receptors of $E$. coli and Pseudomonas (Magazin et al., 1986; Cody \& Gross, 1987; Neilands, 1982) as well as the putative ferrisiderophore receptors of numerous other Gram-negative bacteria (Bachhawat \& Ghosh, 1987; De Weger et al., 1986; Hoe et al., 1985; Meyer et al., 1979; Neilands, 1982; Page \& Huyer, 1984; Williams et al., 1984; Wright et al., 1986). Moreover, iron-limited Azomonas macrocytogenes ATCC 12334 cells transported ${ }^{55} \mathrm{Fe}$ at a higher rate than their iron-sufficient counterparts, which agrees with these bacteria having higher levels of ferrisiderophore receptor proteins in the outer membrane.

Consistent with the notion that Azomonas macrocytogenes has a high-affinity iron uptake system would be the production of a siderophore by iron-limited cells. Under conditions used in this study, none of the strains produced a yellow-green fluorescent compound analogous to that produced by Azotobacter vinelandii as reported by Westervelt et al. (1985); however, iron-limited 
Azomonas macrocytogenes ATCC 12334, NCIB 10958 and NCIB 8700 excreted a blue-white fluorescent compound. Our results confirm observations of Johnstone et al. (1958) and Thompson \& Skerman (1979), who similarly found that iron-limited Azomonas macrocytogenes produces a blue-white fluorescent compound. Johnstone studied the fluorescence characteristics of the compound elaborated by Azomonas macrocytogenes and noted that it was distinct from that elaborated by Azotobacter vinelandii, so much so that he proposed this as a taxonomic criterion for distinguishing the two species (Johnstone, 1957; Johnstone et al., 1958).

We suspect that the blue-white fluorescent compound produced by Azomonas macrocytogenes is a siderophore. Like typical bacterial siderophores (Neilands, 1981), this compound is only produced by iron-limited Azomonas macrocytogenes and appears to chelate iron. Interestingly, $\mathrm{pH}$-dependent shifts in the absorption maximum of the blue-white fluorescent compound and the iron-induced changes in the absorption spectrum are strikingly similar to the properties of the fluorescent siderophores produced by Azotobacter vinelandii (Demange et al., 1988) and the group I fluorescent Pseudomonas spp. (Cox \& Adams, 1985; Demange et al., 1986, 1987; Meyer \& Abdallah, 1978; Philson \& Llinás, 1982; Torres et al., 1986). Furthermore, the fluorescent compound promotes ${ }^{55} \mathrm{Fe}$ uptake in iron-limited Azomonas macrocytogenes ATCC 12334 when supplied in a non-purified form found in cell-free iron-limited culture supernatant fluids. The lower, but definite enhancement of ${ }^{55} \mathrm{Fe}$ uptake in iron-sufficient cells caused by the fluorescent compound is not unexpected since iron-sufficient cells produced basal levels of iron-repressible OM proteins.

Proof of the role of the fluorescent compound as a siderophore must await iron uptake studies with a purified sample since several fluorescent compounds or breakdown products thereof are also present in culture supernatant fluids (S. K. Collinson \& W. J. Page, unpublished results; Johnstone et al., 1958). The purification and chemical characterization of the blue-white fluorescent compound excreted by Azomonas macrocytogenes ATCC 12334 is continuing, and preliminary results indicate that this fluorescent compound is structurally related to other fluorescent siderophores (S. K. Collinson, M. A. Abdallah \& W. J. Page, unpublished results). In view of the taxonomic relationship between Azomonas, Azotobacter and the group I fluorescent pseudomonads as determined by DNA-RNA hybridization experiments (De Smedt et al., 1980), it is not surprising that this group of organisms have structurally similar siderophores.

At this point it is not known whether the fluorescent compounds produced by Azomonas macrocytogenes ATCC 12334, NCIB 10958 or NCIB 8700 are the same structure or variations on a common structure as occurs with the fluorescent compounds elaborated by the various fluorescent pseudomonads (Demange et al., 1987). Nor is it known which of the two OM proteins is the receptor for the fluorescent compound. It is curious that Azomonas macrocytogenes NCIB 9129 did not produce the fluorescent compound nor high levels of the $74 \mathrm{kDa}$ OM protein. While it is tempting to speculate that the $74 \mathrm{kDa}$ protein is the receptor for the ferrated fluorescent compound, this question would be better answered using mutants of ATCC 12334 rather than NCIB 9129, whose genetic relationship to the other strains is not known (Page \& Collinson, 1987).

We thank Park Yee of the Department of Soil Sciences, University of Alberta, for the atomic absorption analyses. This study was supported by a grant from the Natural Sciences and Engineering Research Council of Canada. S. K. C. was funded by a studentship from the Alberta Heritage Foundation for Medical Research.

\section{REFERENCES}

Armstrong, J. MCD. (1964). The molar extinction coefficient of 2,6-dichlorophenol indophenol. Biochimica et biophysica acta 86, 194-197.

BaCHHAWAT, A. K. \& Ghosh, S. (1987). Isolation and characterization of the outer membrane proteins of Azospirillum brasilense. Journal of General Microbiology 133, 1751-1758.

Bingle, W. H., Doran, J. L. \& Page, W. J. (1984).
Regular surface layer of Azotobacter vinelandii. Journal of Bacteriology 159, 251-259.

Brown, M. R. W., Anwar, H. \& Lambert, P. A. (1984). Evidence that mucoid Pseudomonas aeruginosa in the cystic fibrosis lung grows under ironrestricted conditions. FEMS Microbiology Letters 21 , 113-117.

ChOPRA, I. \& Shales, S. W. (1980). Comparison of the 
polypeptide composition of Escherichia coli outer membranes prepared by two methods. Journal of Bacteriology 144, 425-427.

CoDY, Y. S. \& GRoss, D. C. (1987). Outer membrane protein mediating iron uptake via pyoverdin $n_{\mathrm{pss}}$, the fluorescent siderophore produced by Pseudomonas syringae pv. syringae. Journal of Bacteriology 169, 2207-2214.

Collinson, S. K., Doran, J. L. \& Page, W. J. (1987). Production of 3,4-dihydroxybenzoic acid by $\mathrm{Azo}$ monas macrocytogenes and Azotobacter paspali. Canadian Journal of Microbiology 33, 169-175.

Cox, C. D. \& ADAMs, P. (1985). Siderophore activity of pyoverdin for Pseudomonas aeruginosa. Infection and Immunity 48, 130-138.

Demange, P., Wendenbaum, S., Bateman, A., Dell, A., Meyer, J. M. \& Abdallah, M. A. (1986). Bacterial siderophores: structure of pyoverdins and related compounds. In Iron, Siderophores, and Plant Diseases, pp. 131-147. Edited by T. R. Swinburne. New York: Plenum Press.

Demange, P., Wendenbaum, S., Bateman, A., Del. A. \& Abdallah, M. A. (1987). Bacterial siderophores: structure and physicochemical properties of pyoverdins and related compounds. In Iron Transport in Microbes, Plants and Animals, pp. 167-187. Edited by G. Winkelmann, D. van der Helm \& J. B. Neilands. Weinheim, FRG: VCH Verlagsgesellschaft

Demange, P., Bateman, A., Dell, A. \& Abdallah, M. A. (1988). Structure of azotobactin D, a siderophore of Azotobacter vinelandii strain D (CCM 289). Biochemistry 27, 2745-2752.

De Smedt, J., Bauwens, M., Tytgat, R. \& De Ley, J (1980). Intra- and intergeneric similarities of ribosomal ribonucleic acid cistrons of free-living, nitrogenfixing bacteria. International Journal of Systematic Bacteriology 30, 106-122.

De Weger, L. A., VAN BoXTel, R., VAN DER BurG, B., Gruters, R. A., Geels, F. P., Schippers, B. \& LUGTENBERG, B. (1986). Siderophores and outer membrane proteins of antagonistic, plant-growthstimulating, root-colonizing Pseudomonas spp. Journal of Bacteriology 165, 585-594.

ELLS, H. A. (1959). A colorimetric method for the assay of soluble succinic dehydrogenase and pyridinenucleotide-linked dehydrogenases. Archives of Biochemistry and Biophysics 85, 561-562.

Fairbanks, G., Steck, T. L. \& Wallach, D. F. H. (1971). Electrophoretic analysis of the major polypeptides of the human erythrocyte membrane. Biochemistry 10, 2606-2617.

Filip, C., Fletcher, G., WulfF, J. L. \& Earhart, C. F. (1973). Solubilization of the cytoplasmic membrane of Escherichia coli by the ionic detergent sodium-lauryl sarcosinate. Journal of Bacteriology 115, 717-722.

GerhardT, B. \& BEEvers, H. (1968). Influence of sucrose on protein determination by the Lowry procedure. Analytical Biochemistry 24, 337-352.

GREENWOOD, N. N. \& EARNSHAW, A. (1984). Iron, ruthenium, and osmium. In Chemistry of the Elements, pp. 1242-1289. Oxford: Pergamon Press.

GriffitHS, E. (1983). Availability of iron and survival of bacteria in infection. In Medical Microbiology, vol. 3, pp. 153-177. Edited by C. S. F. Easmon, J. Jeljaszewicz, M. R. W. Brown \& P. A. Lambert. London: Academic Press.
Healy, W. B., Cheng, S.-C. \& McElroy, W. D. (1955). Metal toxicity and iron deficiency effects on enzymes in Neurospora. Archives of Biochemistry and Biophysics 54, 206-214.

Hinton,, R. H., Burge, M. L. E. \& Hartman, G. C. (1969). Sucrose interference in the assay of enzymes and protein. Analytical Biochemistry 29, 248-256.

Hoe, M., Wilkinson, B. J. \& Hindahl, M. S. (1985). Outer membrane proteins induced upon iron deprivation of Paracoccus denitrificans. Biochimica et biophysica acta 813, 338-342.

JoHNSTONE, D. B. (1957). The use of a fiuorimeter in the characterization of fluorescing substances elaborated by Azotobacter. Applied Microbiology 5, 103106.

Johnstone, D. B., Pfeffer, M. \& Blanchard, G. C. (1958). Fluorescence of Azotobacter, its chemical nature and bacteriological significance. In. $V I I$ International Congress for Microbiology, 4-9 Aug. 1958, Stockholm (abstracts), pp. 386-387. Edited by G. Tunevall. Uppsala, Sweden: Almquist \& Wiksells.

Kasahara, M. \& AnRaku, Y. (1974). Succinate dehydrogenase of Escherichia coli membrane vesicles. Journal of Biochemistry 76, 959-966.

KNOSP, O., vON TIGERSTROM, M. \& PAGE, W. J. (1984). Siderophore-mediated uptake of iron in Azotobacter vinelandii. Journal of Bacteriology 159, 341-347.

LAEMMLI, U. K. (1970). Cleavage of structural proteins during the assembly of the head of bacteriophage T4. Nature, London 227, 680-685.

LUGTenberg, B. \& VAN AlPHEN, L. (1983). Molecular architecture and functioning of the outer membrane of Escherichia coli and other gram-negative bacteria. Biochimica et biophysica acta 737, 51-115.

Magazin, M. D., Moores, J. C. \& Leong, J. (1986). Cloning of the gene coding for the outer membrane receptor protein for ferric pseudobactin, a siderophore from a plant growth-promoting Pseudomonas strain. Journal of Biological Chemistry 261, 795-799.

Menichi, B. \& BuU, A. (1986). Peptidoglycan association of bacteriophage T5 receptor in Escherichia coli K-12. Journal of Bacteriology 166, 1137-1140.

Meyer, J. M. \& Abdallah, M. A. (1978). The fluorescent pigment of Pseudomonas fluorescens: biosynthesis, purification and physicochemical properties. Journal of General Microbiology 107, 319328.

MeYer, J. M., MocK, M.\& AbdallaH, M. A. (1979). Effect of iron on the protein composition of the outer membrane of fluorescent pseudomonads. FEMS Microbiology Letters 5, 395-398.

Mizuno, T. \& Kageyama, M. (1978). Separation and characterization of the outer membrane of Pseudomonas aeruginosa. Journal of Biochemistry 84, 179191.

NeILANDS, J. B. (1981). Microbial iron compounds. Annual Review of Biochemistry 50, 715-731.

NeILANDS, J. B. (1982). Microbial envelope proteins related to iron. Annual Review of Microbiology 36, 285-309.

NeILANDS, J. B. (1984). Siderophores of bacteria and fungi. Microbiological Sciences 1, 9-14.

Osborn, M. J., Gander, J. E., Parisi, E. \& Carson, J. (1972). Mechanism of assembly of the outer membrane of Salmonella typhimurium, isolation and characterization of cytoplasmic and outer mem- 
brane. Journal of Biological Chemistry 247, 39623972.

PAGE, W. J. (1987). Iron-dependent production of hydroxamate by sodium-dependent Azotobacter chroococcum. Applied and Environmental Microbiology 53, 1418-1424.

PAGE, W. J. \& Collinson, S. K. (1987). Characterization of Azomonas macrocytogenes strains isolated from Alberta soils. Canadian Journal of Microbiology 33, 830-833.

PAGe, W. J. \& HuYer, M. (1984). Derepression of the Azotobacter vinelandii siderophore system, using iron-containing minerals to limit iron repletion. Journal of Bacteriology 158, 496-502.

PAGE, W. J. \& SADOFF, H. L. (1976). Physiological factors affecting transformation of Azotobacter vinelandii. Journal of Bacteriology 125, 1080-1087.

Page, W. J. \& von Tigerstrom, M. (1982). Iron- and molybdenum-repressible outer membrane proteins in competent Azotobacter vinelandii. Journal of Bacteriology 151, 237-242.

Page, W. J. \& von Tigerstrom, M. (1988). Aminochelin, a catecholamine siderophore produced by $A z o t o-$ bacter vinelandii. Journal of General Microbiology 134, 453-460.

Philson, S. B. \& Llinás, M. (1982). Siderochromes from Pseudomonas fluorescens. Journal of Biological Chemistry 257, 8081-8085.

Schnaitman, C. A. (1970). Protein composition of the cell wall and cytoplasmic membrane of Escherichia coli. Journal of Bacteriology 104, 890-901.

Spiro, Th. G. \& Saltman, P. (1969). Polynuclear complexes of iron and their biological implications. Structure and Bonding 6, 116-156.

Thompson, J. P. \& SKerman, V. B. D. (1979). Azotobacteraceae: The Taxonomy and Ecology of the Aerobic Nitrogen-Fixing Bacteria, pp. 196-197, 304. London: Academic Press.

Torres, L., PÉrez-Ortín, J. E., TORDERA, V. \& BELTRÁN, J. P. (1986). Isolation and characterization of an $\mathrm{Fe}$ (III)-chelating compound produced by Pseudomonas syringae. Applied and Environmental Microbiology 52, 157-160.

Westervelt, P., Bloom, M. L., Mabbott, G. A. \& FEKeTE, F. A. (1985). The isolation and identification of 3,4-dihydroxybenzoic acid formed by nitrogen-fixing Azomonas macrocytogenes. FEMS Microbiology Letters 30, 331-335.

Williams, P., Brown, M. R. W. \& Lambert, P. A. (1984). Effect of iron deprivation on the production of siderophores and outer membrane proteins in Klebsiella aerogenes. Journal of General Microbiology 130, 2357-2365.

Winder, F. G. \& O'Hara, C. (1964). Effects of iron deficiency and of zinc deficiency on the activities of some enzymes in Mycobacterium smegmatis. Biochemical Journal 90, 122-126.

Wright, A. C., Simpson, L. M., Richardson, K., Maneval, D. R., JR, Oliver, J. D. \& Morris, J. G., JR (1986). Siderophore production and outer membrane proteins of selected Vibrio vulnificus strains under conditions of iron limitation. FEMS Microbiology Letters 35, 255-260. 